\title{
Introduction to the special issue on Redesigning the Welfare State for Aging Societies
}

\author{
Monika Bütler $^{1}$ • Kerstin Schneider ${ }^{2}$
}

Published online: 4 August 2015

(C) Springer Science+Business Media New York 2015

The edited papers in this special issue of International Tax and Public Finance are drawn from the 70th Congress of the International Institute of Public Finance with a focus on Redesigning the Welfare State for Aging Societies. The challenges are manifold and analyses as well as possible solutions are offered by public economists. Population aging forces us to rethink how promises made to current generations can be kept in the future, without putting too much strain on the fiscal capacity of future generations. The key notes and a substantial portion of research presented at the Congress directly contributed to this important field in public economics. As is tradition of the IIPF congresses, other participants presented their research to broadly cover the entire field of public economics. The papers selected for this special issue reflect the focus of the Congress as well as variety of research in the field of public economics as it was presented and discussed at the Congress.

Of the seven papers in the conference volume of International Tax and Public Finance, the first one is based on a plenary lecture by Axel Börsch-Supan. The keynote "Challenges for European Welfare States" discusses lessons from international comparisons with a focus on Europe. Supported by empirical evidence, he argues that current entitlements may be financed without sacrificing the essence and even most of the current generosity of European welfare states. It is not the insufficient productive capacity to support the welfare state but rather the political decision-making process that creates obstacles for necessary reforms. The negative impacts of demographic aging on financial sustainability of support schemes can be mitigated by the positive

Monika Bütler

monika.buetler@unisg.ch

1 Swiss Institute for Empirical Economic Research (SEQ), University of St. Gallen, Varnbüelstrasse 14, 9000 St. Gallen, Switzerland

2 Schumpeter School of Business and Economics, University of Wuppertal, Gaußstrasse 20, 42119 Wuppertal, Germany 
countervailing forces of international diversification and structural reform. While Axel Börsch-Supan acknowledges that Europe has already made some progress in redesigning the welfare state, he also lists reasons why the political process of redesigning is so difficult.

The remainder of the papers in this volume was submitted for publication after presentations at the Congress. The first two are directly related to the conference topic. Johannes Hagen examines factors which influence cash-out decisions of pension wealth in "The Determinants of Annuitization: Evidence from Sweden." In Sweden, individuals can choose between a lifelong annuity and a payout of phased withdrawal over a fixed period of at least 5 years. Using evidence from Swedish microdata, Johannes Hagen demonstrates that life expectation plays a major role: Individuals with poor health and shorter-lived parents are more likely to opt for the phased withdrawal than for the lifelong annuity. The author also shows that tax incentives play an important role. To avoid paying high marginal tax rates at cash-out, high-income individuals are more likely to opt for a lifelong annuity with lower annual income.

Social security schemes provide insurance for both aggregate and idiosyncratic risk. In their paper "Social Security in an Analytically Tractable Overlapping Generations Model with Aggregate and Idiosyncratic Risk" Daniel Harenberg and Alexander Ludwig explore the impact of both individual wage shocks and aggregate productivity shocks on welfare, taking into account behavioral responses of individuals. The authors develop a theoretical framework based on a two-period overlapping generations model. Although idiosyncratic and aggregate shocks are orthogonal by construction, the insurance value of social security for households is higher than the combined utility value of insurance against each of the two risks in isolation. While the value of social security increases welfare through insurance, its net effect on welfare is ambiguous due to adjustments in savings behavior and capital formation.

Also related to an aging society is the issue of bequests and the tax treatment of bequests. In their paper "Tax Treatment of Bequests when Donor Benefits are Discounted," Robin Boadway and Katherine Cuff develop a theoretical framework to study optimal bequest taxation. As an important novel aspect, externalities in leaving and receiving bequest are explicitly taken into account. In the model, parents and children with heterogeneous skills and wages are subject to income and bequest taxes. Both donors and recipients benefit from bequests. The social externality arises from two sources. First, the government weights the utility of bequest differently from the donors. And the second source of the externality comes from not taking into account the benefit of bequests to inheriting children. In equilibrium, the social welfare attached to parental benefits from making bequests and skill types affect the effective price of bequests. Optimal taxation will depend on the social weight given to donor benefits and the share of donors of a given skill type.

A more general perspective on taxation is taken in the following paper. The effect of taxes on a country's macroeconomic parameters has been a long-standing issue in economics. In "Tax structure and macroeconomic performance" Giampaolo Arachi, Valeria Bucci, and Alessandra Casarico use a panel of 15 OECD countries over nearly four decades to analyze the relation between tax structure, measured as implicit tax rates and tax ratios, and economic performance. Their results show that in the long run, the relation between implicit tax rates and growth is not robust. If tax ratios 
are used, a negative relation between taxation and economic outcomes can be found through changes in labor shares. Short-term effects suggest that switching from taxing production inputs to consumption taxes is positively related to income growth.

The issue of the timing of fiscal adjustment is addressed in "Trust in Government and Fiscal Adjustments" by Dirk Bursian, Alfons J. Weichenrieder and Jochen Zimmer. The paper studies how government trust affects fiscal adjustments over the business cycle. Based on a theoretical model in which the cost of running a surplus depends on the level of trust, the authors develop the hypothesis that trustworthy governments can defer fiscal adjustment to negative shocks to periods with higher growth. In contrast, less trustworthy governments may have to take action immediately, though fiscal adjustments during downturns are more costly. Using a panel of European countries and exploiting Eurobarometer questions regarding trust, the authors find evidence in line with the theoretical expectations.

The optimal structure of federal grants and fiscal decentralization are analyzed in the final paper of this special issue. Emilson Caputo Delfino Silva explores the impact of earmarking grants on fiscal decentralization in his paper "Efficient Earmarking under Decentralized Fiscal Commitments." In the model, a central government distributes grants to subcentral governments and can decide on the degree of earmarking. Subcentral governments have varying degrees of commitment regarding the provision of public goods. If grants are unconditional subcentral governments do not take into account expenditures for public goods of other subcentral entities and they thus have an incentive to overspend. If commitment is in fact a problem, the author shows that earmarking grants potentially provides an efficient solution tackling the issue of overspending.

As editors of this special issue, we wish to thank the authors and referees who contributed to the richness of this volume. We also wish to thank the editors of International Tax and Public Finance for their helpful advice in planning and setting up this volume. Last but not least, we thank the local organizers of the Congress for providing a perfect environment to present and discuss important new research in the field of public economics. The quality of the papers presented in this volume also reflects the attractiveness of the 70th Congress of the International Institute of Public Finance. 